\title{
Symbolic Meaning of the Wind-Journey, Initiation and Identity in Gardens in the Dunes
}

\author{
$\mathrm{Yi} \mathrm{Cai}^{1} \&$ Guiyu Dai ${ }^{2}$ \\ ${ }^{1}$ Faculty of English Language and Culture, Guangdong University of Foreign Studies, Guangzhou, China \\ ${ }^{2}$ Faculty of English for International Business, Guangdong University of Foreign Studies, Guangzhou, China \\ Correspondence: Guiyu Dai, Faculty of English for International Business, Guangdong University of Foreign \\ Studies, Guangzhou 510420, China. E-mail: dgy@gdufs.edu.cn
}

Received: March 7, 2021 Accepted: April 20, 2021 Online Published: April 30, 2021

doi:10.5539/ells.v11n2p33 URL: https://doi.org/10.5539/ells.v11n2p33

\begin{abstract}
Silko, as a writer who attaches great importance to the landscape of the Laguna reservation, accentuates natural elements and imagery in her literary creation. Gardens in the Dunes is the most typical one. This novel is infused with a vast scope of flora and detailed delineation of weather to the extent that some even believe that Silko must be an expert in horticulture and meteorology. "Wind" is one of the most recurrent weather imageries in Gardens in the Dunes, ranging from the literary form of "wind", "breeze" to "storms" and "hurricane". Based on the analysis of the wind's interaction with different characters and the roles it plays, such as "backgrounder", purifier, facilitator, messenger, consoler, mentor and destroyer, the author is dedicated to elucidating that through depicting the "wind" in different circumstances, Silko reveals her advocacy of reconstructing female identity, her denunciation of imperialism and capitalism as well as her reflection on native cultures.
\end{abstract}

Keywords: the image of wind, journey, initiation, identity, Gardens in the Dunes

\section{Introduction}

The story of Gardens in the Dunes is set in the late 19th century. The protagonist Indigo was an eleven-year-old girl who began her transcontinental journey with the white couple-Hattie and Edward - after she escaped from the excruciating boarding school; during the journey she visited various gardens in American, England, and Italy. Having witnessed the hypocrisy and extravagance of the white upper-class people, Indigo finally went back to the old garden in the dunes. In this journey, she had not only achieved her self-growth but also enlightened the people around her, especially her surrogate mother, Hattie.

In the previous study of Gardens in the Dunes, scholars attach great importance to the exploration of strategies of resistance and indigenous views of the environment in this novel. Researchers have analyzed various ways of resistance, among which the traditional ritual of Ghost Dance has been widely discussed. For example, Regier (2005) thinks that "the revolution of Ghost Dance discourse becomes part of the historical fuel feeding the inflamed imaginings of gender and culture revolution in American literary modernism" (p. 137). Ziarkowska (2010) interprets the Ghost Dance in Silko's ideology as an act of resistance to the American colonization, believing that the Ghost Dance "has reestablished the balance between the people and the earth" (p. 140) and "becomes a metaphor of survival whose main components are cultural syncretism and selective adaptation" (p. 142). In Li's (2009) conception, the interweaved activities of gardening, mothering, and storytelling are combined to achieve a powerful means of resistance against oppression and cultural erasure. Li Xuemei (2016) argues that Silko in Gardens in the Dunes seeks for the developing route of gender politics in traveling narrative, and elaborates on the victimization that the white males' colonizing travel inflicts upon Native American in a solemnly realistic tone, to challenge linear development concept of western colonial history and disclose Native American females' rebellion against colonial plunder and racial oppression by means of circular traveling route. Researches have also been done from the perspective of environmentalism. Grounded her work in a decolonial framework, Boyles (2018) highlights the relationship between water rights, climate change, and sovereignty, and promotes environmental practices grounded on indigenous knowledge. Tillett (2020) thinks that Silko's narrative of lived resistance tells us that we need to reject the unsustainable - the established narratives of domination and exploitation - and embrace and enact the sustainable: the indigenous tenets of grounded normativity (p. 206). Based on the above analysis, we could find that the "wind" as a recurrent image in this novel has been neglected 
in the previous study. After a close reading of Gardens in the Dunes, the author finds that the "wind" plays a significant role in the revelation of the themes of this novel, which is worth our further study.

According to Janis P. Stout, Americans are and have always been intrigued by motion. In The Journey Narrative in American Literature (1983), Stout has summarized five patterns, those are "exploration and escape," "the home-founding journey," "return," "quest" and "lost and wandering." In Gardens in the Dunes, Silko has explored the protagonist Indigo's escape from the boarding school, the lost and wandering in the white people's world, and her homing-in journey to the old gardens; in the process of questing, she finally returned to her native place to ascertain her own identity. In the depiction of their transcontinental journey, Silko employs the imagery of "wind" to reveal the features of the character, the themes of the novel, as well as her reflection on native culture, capitalist culture and female identity.

In the following part, based on relevant ideas from bildungsroman, literary geography, and ecofeminism, this essay will first analyze the functions of the "wind" embodied in this novel, and then explore the themes that Silko attempts to reveal through various roles the "wind" has played with relation to different characters, and examine Silko's reflection on native culture through the imagery of wind.

\section{The Wind's Symbolic Roles in Gardens in the Dunes}

According to the Chinese scholar Zou Jianjun (2010), natural imagery is the primary object and content of literary geography criticism (p. 38). "The natural landscape in literary works can be a realistic depiction or a kind of symbol. In essence, all things in literary works are artistic imaginations. They are the psychological images and emotional symbols of writers. In this sense, the natural landscapes in literary works are symbols with meanings" (Zou, 2009, p. 43). With no exception, "wind" in Gardens in the Dunes is also profound in connotation, which not only exposes the inner activity and the deepest emotion of the writer but also sheds light on the themes.

This novel opens with the two sisters chasing, leaping, laughing, and playing in the wind and rain.

She took a deep breath and ran up the dune, where Sister Salt was naked in the rain. She pulled the ragged sack over her head and felt the rain and the wind so cool. So fragrant all over her body. Off in the distance there was a faint rumble of thunder, and the wind stirred; the raindrops were large now. She tilted back her head and opened her mouth wide the way Sister Salt did. The rain she swallowed tasted like the wind. She ran, leaped in the air, and rolled on the warm sand over and over, it was so wonderful (Silko, 2005, p. 13; quotations from Gardens in the Dunes in the following part will only indicate the page number ).

Instead of taking shelter, they came outside, smelling the "heavenly" rain, enjoying the "magic" fragrance of flowers, feeling the "refreshing" breeze and the warmth of the ground. In this case, "breeze" plays the role of backgrounder, which throws into relief a harmonious picture of man and nature. This situation can also be found in the scene of Ghost Dance. Ghost Dance is an important ritual in Indian culture. It is said that "if the Paiutes and all the other Indians danced this dance, then the used-up land would be made whole again and the elk and the herds of buffalo killed off would return" (p. 23). The wind is an indispensable part of this "peaceful" dance. "As the people danced, great storm clouds would gather over the entire world" (p. 23); when all the Indians are dancing, "great winds would roar out of clear skies, winds the likes of which were never seen before" (p. 23), they sing, "Dust of the whirlwind, dust of the mountains in the whirlwind, even the rocks are ringing!" (p. 30). It seems that the wind is livening things up and entertaining the people. It has made the Ghost Dance more sacred and grander, striking one as being God's will.

In some other situations, "wind" is incarnated as a destroyer. When the claimed botanist and in fact botanic smuggler, Edward, initiated his expedition, "a great gust of wind and ocean surge flung the small boat containing all their supplies against the crushed pier" (p. 84-85). Every time the wind appears simultaneously with Edward, its role of destroyer would be intensified. Wind also acts as a destroyer and impartial punisher in the case of Big Candy and Delena. Big Candy ignored his son when Sister Salt took him home, at this moment, "the thunder cracked and shook the ground, and raindrops clattered against the tent while the wind pulled at the canvas and rattled the cottonwood branches and leaves above them" (p. 346), as if protesting against Big Candy's indifference towards his new-born baby. Delena, the "Mexican dog circus Gypsy" (p. 385) stole all Big Candy's money and run off. In the process of escape, Delena "thought she must have reached the edge of the land of the dead or some kinds of hell because a terrible howling wind stung her face with grit and dust" (p. 440), then "the wind increased with the rain and carried with it grit the size of seed beads, then the size of peas; as the wind's scream increased even pebbles the size of small acorns were blasted against her...” (p. 441). The wind is just like an upright judge who abhors any evil-doing and tries to punish the evildoers. 
"Wind" also plays the role of the purifier. In performing the Ghost Dance, "the winds, for weeks without end, would blow away all the topsoil and strip the trees of all leaves; the winds would dry up all the white people and all the Indians who followed the white man's ways, and they would blow away with the dust" (p. 23). When Grandma Fleet, Sister Salt and Indigo were dancing, a Paiute woman commented that "the whirlwind would transform the Earth... when the wind scoured away all impurities, then the Earth's rebirth would follow" (p. 30). Jesus told them "if they kept dancing, great storms would purify the Earth of her destroyers" (p. 23). Wind filters out all the incompatible parts and blows them away, thus maintaining the purity of the nation and bringing regeneration to the earth. In her journey, Sister Salt met Delena, a wandering gypsy who could read cards and made money through dog circuses. Sister Salt noticed "a dark purple scar from the middle of her forehead down the bridge of her nose to her chin" (p. 343), and through further conversation, she realized that it was the war that caused the scar. Sister Salt was quite confused "why the Messiah didn't stop the killers", since "the Messiah told the people here not to take up weapons but to dance until the great storm winds of heaven scoured the earth of killers" (p. 354). However, Delena said that "they were lucky to have the storm winds do the work for them; in the south they had to do the fighting themselves" (p. 354). From the quotations above, we can find that for the indigenous people, the wind has been endowed with perceptivity and the sense of justice. Acting as a healer or purifier, it possesses the power of bringing away all the bad things - wars, injustice, and impurities and bringing in the revival and revitalization of everything on earth.

Besides, wind possesses feelings and can sympathize with people. After losing her temper and shouting at Indigo, Sister Salt was regretful, but she was even more worried about what lied ahead without Mama and Grandma. "The wind rustled the dry cornstalk and leaves as the sun went down... the sound of the wind in the dry stalks seemed like the saddest sound Sister Salt had ever heard; it seemed to say, 'All gone, all gone'...” (p. 56-57). It seems that the wind knows what Sister Salt was thinking and tried to voice out the words in her heart.

Wind is inextricably related to the characters in this novel. Acting as a messenger who conveyed her innermost feelings to the family and a consoler who comforted her in dismay, the wind was a crucial element in Indigo's growing-up process. For Hattie, wind resembled a mentor who guided her and encouraged her to achieve self-actualization rather than being objectified by others. With regards to Edward, who was engaged in botanical piracy, the wind was incarnated as a destroyer, aspiring to devour and demolish every specimen that was ready for the market. Through connecting the image of wind and the characters in this novel, Silko elucidates her advocation of a harmonious human-nature relationship and her reflection on native culture. Meanwhile, she also expresses her support for the reconstruction of female identity as well as her denunciation of imperialism, capitalism, and consumerism. In what follows, the author of this essay will have a detailed analysis of the various roles "wind" has played with relation to different characters and the themes Silko attempts to reveal.

\section{Indigo's Healthy Growth in the Wind}

\subsection{Indigo's Companionship with the Wind}

According to Rui Yuping, an important structural feature of initiation stories is the change of time and space, making the protagonist walk out of the familiar living environment and enter into a strange space to increase knowledge. In doing so, their cognitive development can advance the story along the direction of the theme. This is why many novels have to let the protagonist leave home. It needs to describe the protagonist "on the road" and the story "on the road" (Rui, 2012, p. 286). Centering around Indigo's forced leaving of the familiar Sand Lizard tribe, her deliberate escape from the Indian boarding school, and maturation in the transcontinental journey, Gardens in the Dunes bears the hallmark of the initiation story. The initiation guide is an essential part of the initiation story (Rui, 2004, p. 124). Wind, though impersonal in general understanding, acts as the positive initiation guides in Indigo's growing up process.

In this novel, there are many scenes related to the interaction between wind and Indigo. The wind is just like a loyal friend who understands her, accompanying her going through the toughest days of the journey. When Indigo escaped from the boarding school, she inadvertently entered the white couple's garden, hiding in the lilacs and refusing to come out even though Hattie extended the olive branch. In this moment, the wind guided her to take the first step. "The west wind stirred and cooled her face; she inhaled the scent of orange and lemon blossoms, then suddenly caught the scent of roasted meat that wafted down the path from the back of the house ... she crept out from the low wall ...," the "warm breeze" caresses her skin (p. 83). In this case, wind guided her when she was at a loss and brought solace to her heart.

Wind also resonates with Indigo. "The sounds of the wind in the grass and the nearby waves gave the deserted village a lonely feeling that did not leave Indigo until the carriage pulled around the driveway to the house and she saw Mr. Abbott walking from the stables with two brown-and-white goats on leashes" (p. 181). At that time, 
Indigo was really lonely. She missed her family so much. Previously she got lost and was saved by an Indian woman, who had presented her a button and "she carried the button with her everywhere she went because the button was her first gift from another Indian and because the shell came out of the same ocean she soon must cross" (p. 180-181). The sound of the wind sweeping across the grass and waves made Indigo feel lonelier in this "deserted village", which aroused her emotional resonance and further intensified her nostalgia for the old gardens and her family.

What's more, in Indigo's mind's eye, the wind is a messenger who helps convey her yearnings for the family. When traveling with the white couple, "the great rhythmic voice of Ocean" and "the Earth's moving by her sister Ocean's waves" (p. 224) reminded Indigo of her own sister. "I have a sister too, but this ship and you, Ocean, are taking me farther from her, Indigo whispered ... now a great ocean lay between them ... Tears filled her eyes and she cried softly into her pillow: Please help me, Ocean! Send your rainy wind to my sister with this message: I took the long way home, but I'm on my way. Please don't worry" (p. 224). Though Indigo was "adopted" by the couple and had no need to worry about the material life, her spiritual longing for and attachment to the family and old gardens could never be replaced. Wind, at this time, was metamorphosed as a messenger who shouldered the responsibility of a confidant and the emotion sustenance, listening to her and accompanying her when she was depressed. Cognition of emotion is an indispensable part of initiation stories since the growing up of protagonist must entail his or her emotional maturity, which not only becomes the structural elements of the story but also provides an internal impetus for the plot development (Rui, 2012, p. 237-238). Indigo's emotional maturity is fully manifested in her confession to the wind. She is no longer the little girl who relies heavily on her family, but an independent person who can handle her fickle feelings and make plans for the future.

\subsection{Indigo's Understanding of Nature in Her Interaction with the Wind}

Through the depiction of the interaction between wind and Indigo in the transcontinental journey, this novel suggests that the protagonist has achieved her maturity in emotional, intellectual, personal, and social cognition. Through Indigo's process of growing up, Silko also exhibits to us the indigenous people's harmonious relationship with nature.

Indigo's innocent, amiable, and lovely interaction with "wind" reflects Native people's respect for Mother Earth. The children's attitude towards nature, to some extent, can mirror a nation's view of nature, for the children are influenced and molded by adults, and they will learn from or mimic the behavior of the elder. From this novel, we can find Indigo and Sister Salt's connection with nature was forged and maintained by Mama and Grandma Fleet's storytelling about the old garden. Though she learned from Mama and Grandma that they were forced to abandon the dunes after it was ravaged by starving refugees, Indigo imagined the former old gardens as "tall corn plants swaying gracefully in the breeze, surrounded with bushes of beans pods and black-eyed peas, their golden green tendrils tangled around the thick pumpkin vines" (p. 34-35). It presents us with a vivifying old garden where plants grow freely and luxuriantly, and "wind" (breeze) is an important element in her imagination.

Moreover, Grandma Fleet told the sisters about the essence of Sand Lizard people's way of reseeding: learn to share and "Don't be greedy" (p. 15).

"The first ripe fruit of each harvest belongs to the spirits of our beloved ancestors, who come to us as rain; the second ripe fruit should go to the birds and wild animals, in gratitude for their restraint in sparing the seeds and sprouts earlier in the season. Give the third ripe fruit to the bees, ants, mantises, and others who cared for the plants. A few choice pumpkins, squash, and bean plants were simply left on the sand beneath the mother plants to shrivel dry and return to the earth." (p. 15).

From their ritual after each harvest, we could perceive the Sand Lizard people's reciprocal relationship with Mother Earth. This point echoes with what Merchant (1996) proposes in Earthcare: Women and the Environment - "humans must give nonhuman nature space, time, and care, allowing it to reproduce, evolve, and respond to human actions" (p. 8). The tribe people teach their children to be temperate and grateful to earth, and never monopolize the things presented by nature. This ideology is passed down from generation to generation and becomes an internal part of their beliefs.

Grandma Fleet also instructed the sisters to respect the lives in nature by telling them the stories of the snake. The snake was "almost as old as she was, and the spring belonged to him"; "all desert springs have resident snakes. If people killed the snakes, the precious water disappeared" (p. 36). Through this story, Grandma Fleet cautioned her children: "whatever you do, don't offend the old snake who lives at the spring" (p. 36). Just as Li (2009) observes that the tales from Grandma Fleet "present the world as an integrated universe where the presence of humans is inextricable from the processes of nature" (p. 26). After hearing what Grandma said, Indigo whispered gently to the snake, "Remember us? We won't harm you, Snake" (p. 36). This cute and naïve 
interaction manifests that Grandma's education is effective, and Indigo has internalized this creed of land.

In Indigo's world, everything around her is imparted with life and worth the respect from human beings, such as the wind, the snake, and the land, which epitomizes the indigenous people's view of nature that Silko advocates: rather than exploiting nature without any restraint like some of the white people, the indigenous people's reverence for Mother Earth and peaceful coexistence with other species are adoptable and admirable. It corresponds to what James Lovelock tries to convey in her book, Gaia: A New Look at Life on Earth, which treats the earth as a living organism, proposing that "the entire range of living matter on Earth [...] could be regarded as constituting a single living entity..." (Lovelock, 2000, 9).

The indigenous people's holistic view of land, of nature, and of white people find its full expression in Ghost Dance. Ghost Dance is a continuation of indigenous culture and it is a peaceful dance, "Jesus promised Wovoka that if the Paiutes and all the other Indians danced this dance, then the used-up land would be made whole again and the elk and the herds of buffalo killed off would return" (p. 23). As Ziarkowska comments, "the central motif in Silko's reenactment of the Ghost Dance in Gardens in the Dunes is the recognition of the ancient connection between the people and the earth, in both physical and metaphorical sense" (p. 135).

In performing this dance, we can perceive an intimate communication between native people and the earth. When they were dancing, Indigo found that "they were careful to drag their feet lightly along the ground to keep themselves in touch with Mother Earth" (p. 26); "around and around they danced, lightly caressing the Mother Earth with their feet" (p. 30); "they danced slowly, careful to trail their feet gently to caress Mother Earth" (p. 465). Out of the reverence and love towards land, their movement was tender and soft. In Ghost Dance, multifaceted natural elements have also been incorporated, such as the "wind" that has been analyzed earlier. In this ritual, people would sing, "the wind stirs the willow", "the wind stirs the grasses" (p. 27). In their conception, the universe is an organic whole, and humans and non-human beings are all united together. Though the Paiute woman said that the "wind" in Ghost Dance would clear away the white people as well as the impure things, and the "storm" would purify the Earth of her destroyer, it does not mean that this ritual enhances racial distinctions. On the contrary, it eliminates the boundaries among different racial groups and forges connection instead. For example, Mormons also participated in this ritual. As "the Messiah gave his blessing to the Mormons" (p. 32), the language he spoke is Sand Lizard, not English, "yet the Mormons understood his words and murmured their thanks to him" (p. 32). Silko explains that "in the presence of the Messiah and the Holy Mother, there was only one language spoken - the language of love - which all people understand... because we are all the children of Mother Earth" (p. 32). Through Ghost Dance, Silko has envisioned a harmonious scene where people revere the lives in nature, where all the boundaries are removed "in the wind", and where human beings and non-human beings all live peacefully together.

Indigo learned from the stories that Mama and Grandma Fleet had told her, she was enlightened through what she had observed in the Ghost Dance, and gradually grew up in her interaction with the wind. She became a member of the new generation of Sand Lizard people who inherited the land ethic from her ancestors.

\section{Hattie's Spiritual Awakening in the Wind}

\subsection{Hattie's Pursuit for Independence in the Wind}

In Gardens in the Dunes, Hattie is highly repressed by the male-dominated society. Born in a white middle-class family, she was influenced by her father's research at a young age and got interests in the early church. Hattie's father encouraged her to further her study, and "arranged with the Divinity School to allow Hattie to attend lectures as a nondegree student until she proved she was capable of distinguished graduate work" (p. 95-96). In this process, doubts arose and she challenged the dogma of Christianity, believing that the Gnostic heresies denounced by it were reasonable. Unsurprisingly, the related thesis topic was declined by the thesis committee, which embodied the end of her academic career. Then Hattie went back to the widely accepted track of a woman: marriage. Previously, she believed she would not get married, but Edward changed her mind. In Hattie's view, Edward was "remarkable" (p. 79), for he had been well-traveled to the places that she had never been to, and he was humorous and adventurous, which fascinated her deeply; besides, Edward did not care about whether Hattie was a heretic or not. As a result, she wishfully believed he was the one who would care for her and share her happiness. However, "in the course of their journey, Hattie went through a traumatic realization of being objectified by her husband and abused as an alibi companion to cover up her husband's criminal practices. When she reclaimed her right to independence, she must face the fact that her ex-husband had also ruined her financially. Hattie had to build up an entirely new existence for herself' (Kohler, 2002, p. 240).

In her way to independence, the wind is just like a mentor, illuminating her and leading her to break up the bondage of male chauvinism and realize self-actualization. Hattie's mother Mrs. Abbott had internalized the 
patriarchal values that dominated the whole society and tried to inculcate Hattie with those values. She was not optimistic about her daughter's academic career, holding that few respectable gentlemen want scholars of heresy for wives. According to Mrs. Abbott, Hattie's value could only be realized through marriage rather than her academic achievements. Mrs. Abbott insisted on Hattie taking riding lessons because she wanted "Hattie to develop normal interests and hobbies to take her away from her books long enough to find a suitable husband" ( $p$. 95). However, Hattie didn't share her mother's idea. She galloped her pony in the dunes only because "she loves the rush of the wind in her face and the sensation of flying above the powerful muscles of the horse" (p. 95). A ride in the wind refreshed her and allowed new ideas to spring up. The wind is just like a mentor who inspires her and supports her, giving her time and space for her own independent thinking.

The wind has appeared in another scene which symbolizes Hattie's epiphany. There was a time when Hattie sleepwalked and went to the garden. After waking up, she was quite shocked and tried to trace back her experience there. "Thoughts raced through her mind in swift-moving torrents-glittering and flashing. Words from her thesis notes cascaded before her mind's eye, then suddenly scattered as if suddenly the words were dry leaves blowing away in the wind: poor judgment, bad timing, late marriage, premature marriage, dread of childbirth, sexual dysfunction" (p. 249). All those unbearable memories crowded in her mind, but at that moment, Hattie seemed relieved and could confront those problems calmly. The most urgent one was about the Indian child, Indigo. Hattie's encounter with Indigo "results in her growing awareness of experiences of life that she shares with the Indian girl, since they are ultimately both denied the right to decide on their roles and positions in the American cultural system" (Kohler, 2002, p. 239). When Hattie was contemplating on her own problems, she could somewhat understand Indigo's isolated situation as well as the native girl's inner loneliness. Some further analyze that "Hattie's exclusion from a male-governed intellectual world and Indigo's racial estrangement make for a perfect, unspoken understanding between the two" (qtd. in Kohler, 2002, p. 239). Therefore, in this wind scene, when facing her struggling thoughts and imperfections of life, Hattie suddenly realized that "they must help the Indian child return to her sister and mother!" (p. 249), thus deciding to help Indigo to go back home rather than keep her around.

\subsection{Hattie's Awakening of Female Consciousness in the Wind}

As a female writer from the ethnic group, Silko faces double oppression from the white male society; therefore, topics related to women and their identity are hard to circumvent (Zhao, 2017, p. 184). By depicting the awakening of Hattie's feminist consciousness, Silko is actually elucidating her ideas of the reconstruction of female identity by resisting the male-dominated culture.

Hattie lived in a society that expected women to be docile, passive, and subservient, and new ideas from women are not welcomed, which explains why Hattie's thesis topic had been rejected. She had a keen interest in early Christianity and had planned to continue with graduate study. With her father's help, she was able to attend lectures as a non-degree student at Harvard Divinity School. Though she read and studied with great eagerness, the scholars of early church history were too conservative to accept her topic, and advised that "the committee might have entertained her proposed thesis topic had Miss Abbott not reject all reliable authorities and texts in favor of odd forgeries of old heresies" (p. 101). The committee did not agree with Hattie's heretical views since she challenged both the male scholarly authority and Christian religious predominance. However, "women do not differ from men as rational agents and that exclusion from educational and economic opportunities has prevented them from realizing their own potential for creativity in all spheres of human life" (Merchant, 1996, p. 8). Through Hattie's doomed academic pursuit, Silko attempts to reveal that women's identities and values are denied in a male-dominated society, their voices are submerged in the patriarchal system. Thus, in the following part of this novel, Silko delineates Hattie's awakening and transformation in her identity-seeking journey.

The rejection of her thesis topic was a heavy blow to Hattie, and it "had shaken her self-confidence" (p. 75). "Before the thesis committee's decision, she seldom cared what others might think of her" (p. 75), but after that, Hattie compromised and seriously doubted herself. The first compromise was her marriage. Despite Edward was much older than her and was sexually impaired in his expedition, she determined to marry him. She did not like Edward so much that he was the only one who did not care about her heretic ideas. After that, it became obvious that Hattie gradually conformed to the expectations of society and suppressed her own feelings and desires. Just as Li has analyzed: "She accepts Edward's attempts to commodify plants and flowers and does not challenge Susan's aesthetic exploitation of the earth. Hattie functions largely as an empty vessel to be filled with the beliefs and ambitions of others" (p. 31). However, in the journey, Hattie was deeply influenced by Indigo and began to respect her own opinions and feelings.

When she traveled alone, Hattie received a letter from her father which begged her to go back home. Though 
moved to tears, she refused and would rather "wander naked as Isaiah for years in the wilderness than go back to Oyster Bay to endure the stares and the expressions of sympathy" (p. 452). In her journey to Needles, Hattie was assaulted. All her valuable properties were gone and she was heavily injured. Her family came here to take her to the hospital in Albuquerque, but Hattie escaped. When she finally found the place where she was attacked, Hattie burnt the livery stable of the perpetrator. She was "amazed and elated by the beauty of the colors of the fire against the twilight sky" (p. 473), and the "white town" (p. 473) Needles was burnt to the ground. As Regier comments, "Hattie's barn and town fire, metonymically burning down a culture, parallels the attempt to burn the patriarchal barn in William Faulkner's 'Barn Burning' (1938), as well as the burning of colonial structures in Jean Rhys's Wide Sargasso Sea (1966)" (Regier, 2005, p. 153). The arson was the first time that Hattie showed her aggression and initiative, which demonstrates her awakened female consciousness and resistance to the male-dominated society. At the end of the story, Indigo received a letter from Hattie and was relieved to find that she lived a happy life in England.

From Hattie's experience, Silko attempts to convey that women in a patriarchal society should break the bondage that men imposed on them, and try to pursue independence rather than being defined by other people. Only by doing so can they affirm their subjective position and realized their own values.

\section{Edward's Doom Manifested in the Wind}

\subsection{The Wind's Rage Against Edward's Money Worship}

Edward was a white botanist who smuggled forbidden plant material for lucrative interest. He was an indifferent capitalist machine who cared only about money and profits. Putting too much of his energy into profit-making, Edward communicated less with his wife; fighting over the property rights, he was estranged from his sister Susan; trying to train the Indigo to be a maid and servant, he showed no sympathy for the poor girl. He even risked his life to pirate orchids and citron and sought meteorites for valuable metals and diamonds.

In Gardens in the Dunes, whenever wind appears simultaneously with Edward, it takes the role of a destroyer, as if it is nature's revenge for his smuggling of rare plants. When they were in the Key West expedition, "an early hurricane" cut short their journey when "the tropical storms lashed the Bahamas and the Keys," so they decided to "wait out the first storm"; however, "a great gust of wind and ocean surge flung the small boat containing all their supplies against the crushed pier" (p. 84-85). Edward tried to send a telegram to extend the effective dates of their expedition, "but the high winds from the approaching storm knocked out telegraph communication" (p. 85). The captain said that "in more than thirty years on the Caribbean...[he] had not seen as many storms as there were this season" (p. 88). "The wind howled and drove the rain relentlessly against the ship; on the third day the storm gave no sign of abating, and the sailor began to recount old stories about hurricane that raged for weeks" (p. 88).

It was not the first time that Edward was up against the hurricane. In his return trip from the Pará expedition, "a sudden storm sprung up off the coast of Venezuela", "wind-driven waves nearly swamped the ship; the terrified sailors cast overboard much of the ship's cargo to buy the wind's mercy, and all but two crates of the rare orchids specimens were lost" (p. 88). "The rain and wind were relentless, never increasing but never decreasing in velocity" and "the relentless howling of the wind brought on a deafness in his right ear" (p. 89). The wind is never a friend to Edward. He was always under the menace of its various forms, the "storm" or the "hurricane." The specimens painstakingly collected by him were frequently subject to the devastation of the wind: "... a rainstorm and wind threatened to flood the boxed of orchid specimens" (p. 147), "a great gust of wind and ocean surge flung the small boat containing all their supplies against the crushed pier" (p. 84-85).

Under such circumstances, the wind has incarnated as an impartial judge. Having witnessed various injustices and immoralities done by the profit-driven human world, it decides to eradicate all the harms for constructing a more harmonious man-and-nature relationship.

The wind also voices its dissatisfaction when Edward neglected his family. When Edward had just bought the lead curse tablets from the major, he was pleased with his purchases and wondered how marketable the tablets would be, considering "pleading a headache to excuse himself from the picnic so he could spend time with his new acquisition" (p. 259). At this moment, “... the clear sky and sun gave way to dark blue storm clouds and wind-driven rain. The sky darkened, so hall lamps were lit by two o'clock. As the afternoon wore on, the wind blew harder and the creak and groan of the roof timbers could be heard, along with other noises in the wind - clatters and bangs of loose shutters..." (259). Before long, "the wind made a howling sound like the sea monsters in stories Aunt Bronwyn heard as a child. The monsters were not flesh and blood but the great violent storms that lashed these islands..." (259). Edward was a typical merchant, who cared solely about profits rather than the warmth of family. In most situations where "wind" and Edward appear simultaneously, the former plays 
the role of a "destroyer," seemingly trying to devour and demolish everything in the human world. It is not surprising that Edward finally faced his doom in a desolate way.

\subsection{Destruction of Money-Worshipped Edward in the Wind}

The howling of the wind not only voices the indignation of nature but also reflects Silko's denunciation of the anthropocentric and profit-driven capitalism. As Ryan argues, "In Gardens plants are exquisite tokens that signify the international imperialism behind the botanical piracy in which Edward and his employers engage" (Ryan, 2007, p. 127). The mechanism behind capitalism drives people to maximize their profits by every means. Rather than regarding plants as edible or ornamental, the white people view them as a symbol of social status and means of making profits. As a result, they throw a cold shoulder to the family warmth and ecological equilibrium, plunging headfirst into consumerism to find their life meaning. Edward finally broke up with Hattie and was alienated from his sister, dying a desolate death. His tragic end demonstrates Silko's severe reprimand of the alienation brought about by capitalism.

This point is also manifested in the comparison of people's different attitudes towards money. For Edward, money was everything. He risked his life to participate in the ruthless botanical exploitation in the name of a private collection. He was not an authentic botanist, for he was fascinated by the money represented by those plants rather than their value for academic research. The dog circus woman Delena's "eyes widened at the mention of money" (p. 352), and her "dark eyes lit up when Sister Salt described the canvas money-bags Big Candy delivered to the boss" (p. 353). Finally, she stole Candy's money and began her fugitive journey. Big Candy, in order to get his money back, abandoned Sister Salt and his newborn son and chased after the Gypsy woman for his savings. People believed that "a man, white or colored, was nothing without money" (p. 387). However, it is not true of the indigenous people. For example, Sister Salt was at first "excited by the stacks of silver she earned", "but she was tired of money, tired of the noise the boredom and the dust required to make money; tired of the worry money caused over thieves and floor safes buried in the sand" (p. 352). She also lamented that "Money! You couldn't drink it or eat it, but people went crazy over it" (p. 398). It expressed Silko's attitude towards money. In a profit-driven world, people are estranged from each other, and family, friendship, and love are no longer important for them: because of money, Edward divorced his lovely wife, Susan disregarded her dying brother, Big Candy abandoned his new-born son, and Delena betrayed her trustworthy friends. The relationship she really admired is that of the native people. In their separate journey, Sister Salt and Indigo were concerned about each other and missed their family and home; the friendly Indian woman helped Indigo when she got lost and refused Hattie's father's reward, etc.

Moreover, through comparing people's different attitudes towards plants, Silko also expresses her advocation of the plant wisdom of native people. For Edward, plants such as orchid were for profits; for Susan, flowers were for ornament and display. However, Indigo collected seeds in her transcontinental journey, which was a tribal tradition that she had inherited from Grandma Fleet. "Others did not grow a plant unless it was food or medicine, but Sand Lizards planted seeds to see what would come" (p. 84). As Cole has analyzed, Edward's "entitlement to the almighty dollar compels him to steal, to harm the citron as a whole for the sake of the sample, and to create Americanized hybrids that degrade the quality of the original. In contrast, Indigo always receives her seeds as either gifts or lucky finds in wild spaces, and as seeds there is minimal ethical conflict for replanting them, particularly because she does not intend to profit from her collection" (Cole, 2018, p. 15). Nature has bestowed our human beings a lot of things for free, and we should observe the law of nature rather than ravage it just for material gains.

Silko here criticizes the estrangement of human relationships within themselves and with nature, reprimands the changes that commodity fetishism has induced, and highly praises the values and natural views of native people.

\section{Conclusion}

Silko, as a writer who attaches great importance to the landscape of the Laguna reservation, accentuates natural elements and imagery in her literary creation. Gardens in the Dunes is the most typical one. This novel is infused with a wide scope of flora and detailed delineation of weather to the extent that some even believe that Silko must be an expert in horticulture and meteorology. In Gardens in the Dunes, the frequent occurring of wind is no coincidence. Actually, Silko is exercising her inventive mind when she employs this imagery. With relevance to different characters, the wind takes on different roles - such as backgrounder, purifier, facilitator, messenger, consoler, mentor, and destroyer, which helps the revelation of different themes. For Indigo, the wind is like a loyal friend, who helps convey her innermost feelings to the family and comforts her in dismay. Through the depiction of her initiation in the transcontinental journey, Silko praises the native people's attitude towards nature: they revere Mother Earth and coexist peacefully with other species. For Hattie, the wind resembles a 
mentor who guides her way to independence and self-actualization. In the delineation of her independent journey, Silko is advocating a reconstruction of female identity in the male-dominated world. Rather than being passive and subservient to men, women should have their independent thinking, make decisions for themselves, and should resist when injustice happens. As for Edward, the wind is incarnated as an impartial judge and a destroyer, who aspires to devour and demolish everything that he holds dear to make profits. In his profit-making journey typical of capitalism, Edward not only brings damages to nature but also neglects his family, which is severely denounced by Silko. All in all, wind as an essential imagery in Gardens in the Dunes is of significant thematic concern.

\section{References}

Boyles, C. (2018). Writing Water, Writing Life: Silko as Environmental Activist. Studies in American Indian Literatures, 30, 10-35. https://doi.org/10.5250/studamerindilite.30.3-4.0010

Cole, A. (2018). Growing Against the Grain: Confronting White Supremacy and Patriarchy in Gardens in the Dunes. University Honors Theses. https://doi.org/10.15760/honors.641

Kohler, A. (2002). "Our human nature, our human spirit, wants no boundaries”: Leslie Marmon Silko's Gardens in the Dunes and the Concept of Global Fiction. American Studies, 47, 237-244.

Li, S. (2009). Domestic Resistance: Gardening, Mothering, and Storytelling in Leslie Marmon Silko's Gardens in the Dunes. Studies in American Indian Literature, 2, 18-37. https://doi.org/10.1353/ail.0.0060

Li, X. M. (2016). Traveling Politics in Gardens in the Dunes. English and American Literary Studies, 2, 227-240. https://doi.org/10.16754/b.cnki.ymwxyjlc.2016.02.018

Lovelock, J. (2000). Gaia: A New Look at Life on Earth. London: Oxford University Press.

Merchant, C. (1996). Earthcare: Women and the Environment. New York: Routledge.

Regier, A. M. (2005). Revolutionary Enunciatory Spaces: Ghost Dancing, Transatlantic Travel and Modernist Arson in Gardens in the Dunes. Modern Fiction Studies, 51, 134-157. https://doi.org/10.1353/mfs.2005.0014

Rui, Y. P. (2004). A Study of American Initiation Stories. Beijing: China Social Science Press.

Rui, Y. P. (2012). Visions of Adolescence Growth: A Study of Contemporary American Initiation Stories. Beijing: The Commercial Press.

Ryan, T. (2007). The Nineteenth-Century Garden: Imperialism, Subsistence and Subversion in Leslie Marmon Silko's Gardens in the Dunes. Studies in American Indian Literature, 19, 115-132. https://doi.org/10.1353/ail.2007.0025

Silko, L. M. (2005). Gardens in the Dunes. Simon \& Schuster Paperback.

Stout, J. P. (1983). The Journey Narrative of American Literature. Greenwood Press.

Tillett, R. (2020). The Necessity of Lived Resistance: Reading Leslie Marmon Silko's Gardens in the Dunes in an Era of Rapid Climate Change. Studies in American Indian Literatures, 32, 188-207. https://doi.org/10.5250/studamerindilite.32.1-2.0188

Zhao, L. (2017). A Study of Leslie Marmon Silko's Novel. Beijing: People's Daily Press.

Ziarkowska, J. (2010). Dancing for Survival: Reinterpretations of the Ghost Dance in Leslie Marmon Silko's Gardens in the Dunes. Retrieved October 16, 2020, from http://journals.theasa.net/images/contributor_uploads/PJAS_vol4_12Ziarkowska.pdf

Zou, J. J. (2009). The Main Field of Study in Literary Geography. The World Literature Criticism, 1, 41-46.

Zou, J. J. (2010). Ten Pairs of Key Words in the Research of Literary Geography. Journal of Anhui University (Philosophy and Social Sciences Edition), 2, 35-43.

\section{Copyrights}

Copyright for this article is retained by the author, with first publication rights granted to the journal.

This is an open-access article distributed under the terms and conditions of the Creative Commons Attribution license (http://creativecommons.org/licenses/by/4.0/). 